\title{
Property Rights Orientations and Rangeland Management Objectives: Texas, Utah, and Colorado
}

\author{
Urs P. Kreuter, ${ }^{1}$ Malini V. Nair, ${ }^{2}$ Douglas Jackson-Smith, ${ }^{3}$ \\ J. Richard Conner, ${ }^{4}$ and Janis E. Johnston ${ }^{5}$ \\ Authors are ${ }^{1}$ Associate Professor, Department of Rangeland Ecology \& Management, Texas A\&M University, College Station, \\ TX 77843; ${ }^{2}$ Consultant, Bearing Point, New York, NY 10024; ${ }^{3}$ Associate Professor, Department of Sociology, Social Work and \\ Anthropology, Utah State University, Logan, UT 84322; ${ }^{4}$ Professor, Department of Agricultural Economics, \\ Texas A\&M University, College Station, TX 77843; and ${ }^{5}$ Research Associate, Department of Sociology, \\ Colorado State University, Ft. Collins, CO 80523.
}

\begin{abstract}
In response to substantial economic and social dislocations in the United States, many rangeland owners are changing land use and management practices. Changes in land use can significantly affect the services rangeland ecosystems provide. Decisions associated with such changes are likely mediated by landowner views regarding individual rights, social responsibilities, and the future security of property rights. In this paper, we examine the extent to which landowners are likely to adopt, without public compensation, socially desirable land management objectives that enhance ecosystem services from rangelands. The study consisted of a mail survey of landowners with at least 40 ha: 500 in Texas, 500 in Utah, and 694 in Colorado. Adjusted response rates were $62 \%$ in Texas, $46 \%$ in Utah, and $51 \%$ in Colorado. Regression analyses showed that willingness to adopt socially desirable rangeland management objectives was positively correlated with the social responsibility dimension of respondents' property rights orientations but negatively correlated with the rights erosion dimension. Our results also suggested that landowners in private land states, such as Texas, might be less willing than landowners in states with more public land to manage their land for the maintenance of ecosystem services without being compensated. Although the scope of our study was limited, the results suggest that agencies tasked with maintaining ecosystem services on private rangelands might more successfully achieve their mission by promoting social responsibility among landowners. Including community leaders with a highly developed sense of social responsibility in programs aimed at improving land stewardship and including peer-pressure incentives in such programs might enhance social responsibility perspectives among landowners. Such programs should also be adaptable at the state-level to account for differences in property-rights orientations relative to landowner dependence on private and public land.
\end{abstract}

\section{Resumen}

En repuesta de las confusiones substanciales sociales y económicas en los Estados Unidos de América, muchos de los propietarios de pastizales están cambiando el uso del terreno y las prácticas de manejo. Los cambios en el uso de la tierra puedes afectar significativamente los servicios que el ecosistema de pastizal provee. Las decisiones asociadas con tales cambios probablemente son mediadas por los puntos de vista de los propietarios con respecto a los derechos individuales, responsabilidades sociales y seguridad futura de los derechos de la propiedad. En este articulo, examinamos que tan dispuestos están los propietarios de los terrenos a adoptar, sin una compensación pública, los objetivos de manejo de la tierra socialmente deseables que mejoran los servicios del ecosistema del pastizal. El estudio consistió de una encuesta por correo a los propietarios de los terrenos con al menos 40 ha: 500 en Texas, 500 en Utah, y 500 en Colorado. Las tasas ajustadas de respuesta fueron $62 \%$ en Texas, $46 \%$ en Utah y $51 \%$ en Colorado. Los análisis de regresión encontraron que la disposición para adoptar los objetivos de manejo del pastizal socialmente deseables estuvo positivamente correlacionada con la dimensión de responsabilidad social de la orientaciœn de los derechos de propiedad de los propietarios que respondieron las encuestas y correlacionada negativamente con la dimensiœn de los derechos de erosión. Nuestros resultados también sugieren que los propietarios de tierras en los estados con terrenos privados, como Texas, pueden estar menos dispuestos que los propietarios de los estados con terrenos públicos a manejar su tierra para mantener los servicios del ecosistema sin ser recompensados. Mientras que el alcance de nuestro estudio fue limitado, los resultados sugieren que las agencias a cargo de mantener los servicios de los ecosistemas en pastizales privados pudieran alcanzar su misión más exitosamente al promover la responsabilidad social entre los propietarios. Los programas enfocados a mejorar la administración pueden también ser una herramienta útil para promover un sentido de responsabilidad social entre los propietarios de los terrenos. Los programas para cambiar el manejo de los pastizales deben ser adaptables a nivel de estado para tomar en cuenta las diferencias en la orientación de los derechos de propiedad relativos a la dependencia del propietario en las tierras públicas y privadas.

Key Words: landowner attitudes, land management, rangelands, social responsibility

This project was supported by the National Research Initiative of the Cooperative State Research, Education and Extension Service, USDA, Grant 00-35401-9255.

The manuscript is based on research results included in the PhD Dissertation of M.V.N. Correspondence: Urs P. Kreuter, Dept of Rangeland Ecology and Management, Texas A\&M University, 2126 TAMU, College Station, TX 77843-2126. Email: urs@tamu.edu

Manuscript received 13 October 2005; manuscript accepted 4 September 2006

\section{INTRODUCTION}

In recent years, ranchers in the United States have experienced substantial economic and social dislocations due to low livestock prices, declining rangeland productivity, and more stringent environmental regulations (Knight et al. 2002). 
Further, many ranchers are living within or near rapidly growing communities where land is being increasingly subdivided (McGranahan 1999). In response to such pressures, many ranchers are making changes in their land management practices, business enterprises, and future land-use plans. Such actions can significantly impact the structure and integrity of rangeland landscapes and the ecological, economic, and aesthetic services provided by them (Kreuter et al. 2001a). To an extent, land management decisions are mediated by landowners' views regarding the balance between individual rights and social responsibilities, as well as their perceptions about the future security of their property rights.

The objective of our research was to determine whether accounting for property rights orientations can explain variability in landowner attitudes towards the adoption of socially desirable rangeland management practices that enhance ecosystem services. We hypothesized that landowners' property rights orientations affect their willingness to assume socially desirable land management objectives without receiving financial incentives to do so.

Our study constitutes an expanded pilot study, conducted to obtain information for a more comprehensive future study. It was conducted in 6 counties with extensive rangelands; 2 each in Texas, Utah, and Colorado. Whereas 95\% of Texas rangelands are privately owned, large parts of Utah $(64 \%)$ and Colorado (36\%) consist of public land. The reason for locating the study in these states is that they have population growth rates in rural areas that exceed the national average (Perry and Mackun 2001). Many rural communities in these states are facing changes in ownership and land use that will increasingly affect other western states.

\section{Traditional Factors Affecting Land Management Decisions}

There is extensive literature on the socio-demographic, economic, and policy factors that affect management decisions on private agricultural land in the United States, and studies have shown that biophysical, socioeconomic, and cultural factors interact in complex ways to influence the use of a wide range of conservation practices (Jackson-Smith 2004). Variables found to be important determinants of conservation behavior include: (a) characteristics of the farm or ranch business (size, crop mix, labor availability, tenure status); (b) demographic characteristics of the land manager (age, education, income, and experience); (c) psychological traits of land decisionmakers, including attitudes and beliefs on a wide range of issues; and (d) the interaction of these factors with incentives or disincentives created by public policies (Korsching and Hoban 1990; Nowak 1992; Guerin 1999; Napier et al. 2000). In general, traditional variables used in the analysis of conservation behavior have only explained a relatively small percent of the overall variance in the behaviors of interest (Napier 2000; Fuglie and Kascak 2001).

Land use behaviors have also been explored with respect to rangeland management. Variables found to significantly affect ranch management decisions in Utah include ability and willingness to incur more debt, income level, and community involvement (Peterson 1997). Another study of Utah livestock producers that rely on public and private rangeland found a positive correlation between ranch income and the implemen- tation of ecologically sound rangeland management practices; hobbyists with less than $50 \%$ of their income from livestock sources seldom applied such practices (Coppock and Birkenfeld 1999). Similarly, small-acreage ranchers in Texas were more concerned about increasing stocking rate than improving rangeland condition and they tended to rely on quick-fix solutions to achieve this goal (Rowan 1994), whereas larger ranching operations gave greater consideration to nontraditional factors affecting stocking rates (Rowan et al. 1994). The extent to which ecologically sound management practices are implemented by landowners can also be affected by the availability of user-friendly information, and the emphasis on short-term efficacy of such practices (Kreuter et al. 2001b).

Enhancing adoption of sustainable rangeland management practices requires a clear understanding of landowners' goals and available resources (White 1988). Researchers and extension staff have often erroneously assumed that profit maximization will motivate the adoption of "good" technology (Workman and Evans 1996). Instead, social factors, such as lifestyle choices, have been found to frequently dominate rural landowners' goals and decisions (Workman and Evans 1993; Rowan 1994).

\section{The Role of Property Rights Orientations}

Although scholars have developed elaborate theoretical models to explain the origin and nature of property rights in modern society (Honoré 1961; Bromley 1991; Anderson and McChesney 2003), the understanding of property rights attitudes and beliefs among ranchers has only recently come under systematic empirical scrutiny. In their recent paper, JacksonSmith et al. (2005) categorized rangeland owners' property rights orientations into 4 distinct dimensions. These dimensions and the associated key concepts include: (a) individual rights (exclusive access and right of use for owned rangeland, and transferability of such ownership); (b) social responsibilities associated with property ownership (natural resources belong to society, sensitivity to societal values, and obligation to consider societal values), (c) land stewardship (obligation to be a good land steward, leave land in better shape, and non-conflict with neighbors and community); and (d) rights erosion or threats to the security of individual property rights (reduced civil liberties and more restriction on landowners' rights over time).

Cole (2002) has argued that various ownership institutions (or property rights regimes) create different incentives and disincentives for environmental protection. Although it is probably overly simplistic to view 1 type of property rights regime as superior to others for the purposes of promoting environmentally responsible behavior, it is widely accepted that welldefined property rights can enhance land managers' ability to respond to unanticipated changes (Harnett-White 1994), whereas poorly-defined property rights often lead to ecosystem degradation (Bliss et al. 1998). Hardin (1968) argued that under conditions of increasing population pressure, poorly defined or unenforceable rights inevitably lead to the overexploitation of natural resources.

More recent research has clarified the important role of welldefined communal property rights institutions in governing the use of common-pool resources (Berkes and Folke 1998; Ostrom 2001). Some have argued that good resource stewardship 
depends on how well social institutions harness self-interest through individual incentives, because it is the individualistic process that rewards the efficient use of time and place specific information (Anderson and Leal 1991; Wiebe et al. 1999; Anderson and McChesney 2003). Others have identified social pressure as a key mechanism for regulating individual behavior in rural landscapes. For example, Australia's "Landcare" program was developed to change landowner attitudes towards land management by implementing peer group pressure mechanisms to improve land stewardship (Young and McCay 1995; Curtis 1998). The success of this participatory program in enhancing effective catchment-level land management was made possible by the creation of an institutional mechanism for linking the activities of local management groups (Curtis and Lockwood 2000).

\section{METHODS}

\section{Mail Survey}

A survey questionnaire was mailed to 1694 rangeland owners in Texas, Utah, and Colorado. In each state, 1 county with population growth above the state average (high growth) and 1 with growth below the state average (low growth) between 1990 and 2000 were selected along a transect line centered on a major urban area. The selected high and low growth counties included (10-year change in parentheses): Llano $(46.5 \%)$ and Sutton $(-1.4 \%)$ in Texas $(22.8 \%)$, Summit $(91.6 \%)$ and Uintah $(13.6 \%)$ in Utah $(29.6 \%)$, and Routt $(39.8 \%)$ and Moffat $(16.1 \%)$ in Colorado $(30.6 \%)$.

A mail survey instrument was developed based on a literature search and a structured interview of 14 and 15 landowners in Texas and Utah, respectively, to identify major issues concerning landowners' property right orientations and land management decisions. The main areas of inquiry in the questionnaire included landholding characteristics, perceptions about rights and responsibilities of landowners, land-management practices, and landowner socio-demographic information. Following pretests and revision, the survey questionnaire was mailed to randomly selected landowners who owned at least 40 ha of land. The 40 ha cutoff was used to exclude landowners whose holdings are too small to provide meaningful rangelandbased income and who would most likely engage in minimal rangeland management activities. Mailing addresses of landowners were obtained from County Tax Appraiser mailing lists. In Texas and Utah, the questionnaire was mailed to 250 randomly selected landowners in each county; in Colorado it was sent to a total of 694 randomly selected landowners. The mail survey was administered using the Dillman (2000) multiple contact method. The survey was conducted in 2002, with the first mailing occurring on 20 February.

\section{Measurement of Key Concepts}

The key dependent variables represent measures of landowner willingness to adopt socially desirable land management objectives, the achievement of which requires ecologically sound management practices. Specifically, we focus on responses to the question, "To what extent do you agree that you should be required to do each of the following things with your land without any compensation from the public?" This question was asked with respect to 6 socially desirable land management objectives including: (1) control noxious weeds, (2) protect water quality and supply on the property, (3) protect water quality and supply for downstream users, (4) protect wetland and riparian areas, (5) provide access to property for hunting of native species, and (6) protect habitat for threatened and endangered species. The survey participants were not provided with information about costs and types of practices needed to address these objectives. The response options ranged from strongly agree $(+3)$ to strongly disagree $(-3)$.

A factor analysis (Norusis 1990) was conducted to determine the extent to which responses to this question for the 6 listed land management objectives were interrelated and, thus, identify subsets of response variables that could be combined into additive indices. Specifically, Principal Components Analysis was used in which factors having an Eigenvalue greater than 1 are considered to constitute representative indices or subscales (Norusis 1990). Varimax rotation was used to minimize nonzero loadings of the variables on each extracted index. Further, a Cronbach's alpha analysis was conducted to determine the internal consistency and reliability of each index (Statsoft Inc. 2004). The resulting indices or subscales represent a generalized measure of the willingness of landowners to adopt certain categories of land management objectives, and they provided more robust dependent variables for the ensuing multivariate analysis than measures of willingness to adopt individual objectives.

Once robust indices were identified for the 6 socially desirable land management objectives included in our study, we conducted 3 ordinary least squares regression analyses to identify independent variables that could explain differences in respondent willingness to adopt these objectives. Four groups of independent variables were included in the analysis; see Table 1 for mean sample values for each variable. The first group consisted of 6 socio-demographic variables: respondent age, education, ranching experience, place they grew up, place of residence, and level of household income. The second group included 6 property and enterprise characteristics: hectares owned; reliance on crop, livestock, wildlife/recreational income; dependence on income from property; and ranch profitability. The third group focused on property rights orientations, specifically the 4 distinct dimensions identified by Jackson-Smith et al. (2005): individual rights, social responsibilities, land stewardship obligations, and rights erosion. The fourth group consisted of dummy variables to identify interstate differences.

Given that our study represents an expanded pilot study, we adopted a $90 \%$ level of confidence to identify marginally important explanatory variables for further investigation in more comprehensive future research. As the results show, the use of the more commonly adopted $95 \%$ level of precision could have eliminated several potentially important variables from further consideration.

\section{RESULTS}

\section{Response patterns}

The response rates were determined based on the actual number of landowners who were qualified survey participants, i.e., those 
Table 1. Interstate statistical differences of variables used in regression analyses. The mean values for the property rights indices represent the average of additive response values for variables found by Jackson-Smith et al. (2005) to represent four dimensions of landowners' property right orientations. Bold probability values highlight variables exhibiting significant interstate differences at $P<0.050$.

\begin{tabular}{|c|c|c|c|c|c|c|}
\hline Variable & All & Texas & Utah & Colorado & Test statistic & $P$ value \\
\hline Mean age of respondent & 59.8 & 59.3 & 61.7 & 59.1 & $F=2.25$ & 0.107 \\
\hline Formal education (college degree) & $44 \%$ & $61 \%$ & $35 \%$ & $37 \%$ & $\chi^{2}=48.0$ & $<0.001$ \\
\hline Mean years of experience & 30.3 & 27.2 & 33.8 & 30.6 & $F=5.48$ & 0.004 \\
\hline Grew up on property & $74 \%$ & $67 \%$ & $82 \%$ & $73 \%$ & $\chi^{2}=7.4$ & 0.024 \\
\hline Currently living on property & $44 \%$ & $48 \%$ & $70 \%$ & $29 \%$ & $\chi^{2}=64.5$ & $<0.001$ \\
\hline Total annual household income $(<\$ 50000)$ & $39 \%$ & $22 \%$ & $50 \%$ & $45 \%$ & $\chi^{2}=44.6$ & $<0.001$ \\
\hline Mean hectares owned & 1082 & 1477 & 1146 & 810 & $F=1.59$ & 0.204 \\
\hline Crop income & $18 \%$ & $4 \%$ & $23 \%$ & $24 \%$ & $F=28.98$ & $<0.001$ \\
\hline Wildlife and recreational income & $15 \%$ & $27 \%$ & $5 \%$ & $14 \%$ & $F=33.09$ & $<0.001$ \\
\hline Livestock income & $54 \%$ & $58 \%$ & $66 \%$ & $45 \%$ & $F=14.99$ & $<0.001$ \\
\hline $\begin{array}{l}\text { Percent of respondents who earned }<10 \% \\
\text { of their income from their land }\end{array}$ & $43 \%$ & $48 \%$ & $46 \%$ & $39 \%$ & $\chi^{2}=12.0$ & 0.017 \\
\hline Profit in 2001 & $28 \%$ & $26 \%$ & $36 \%$ & $26 \%$ & $\chi^{2}=20.2$ & $<0.001$ \\
\hline Mean individual rights index & 5.44 & 6.69 & 5.82 & 4.50 & $F=19.52$ & $<0.001$ \\
\hline Mean social responsibility index & -1.47 & -1.73 & -1.51 & -1.28 & $F=0.52$ & 0.596 \\
\hline Mean land stewardship index & 4.70 & 4.86 & 4.61 & 4.65 & $F=0.67$ & 0.513 \\
\hline Mean rights erosion index & 6.14 & 6.30 & 5.81 & 6.21 & $F=0.96$ & 0.382 \\
\hline
\end{tabular}

who reported having at least 40 ha and who earned at least some income from ranching activities on their land. Based on the adjustment for nonqualified respondents, the response rates were $62 \%$ in Texas, $46 \%$ in Utah, and $51 \%$ in Colorado.

The overall mean response values for implementing each of the 6 listed land management objectives without compensation, and the significance of interstate differences among these responses are presented in Table 2 . On average, respondents were not indifferent to the idea of being required to meet certain socially desirable land management objectives, even if they did not receive public compensation. Respondents agreed most strongly with the idea of protecting the quality and supply of water that is used directly on their land or by downstream users. They were more ambivalent about controlling noxious weeds and protecting wetlands and riparian areas for public benefit without compensation. By contrast, respondents generally disagreed with the idea of being required to provide habitat for threatened or endangered species or providing access to their land for hunting without receiving compensation.

Although the positive response values for protecting water for downstream users and the negative response values for providing free hunting access did not differ significantly across the 3 states, there were significant interstate differences in response values for the other 4 rangeland management objectives. Texas respondents were significantly less inclined than Utah respondents to protect the supply of quality water for onproperty use and to control noxious weeds, and they were less inclined than the Colorado respondents to control noxious weeds and protect wetland/riparian areas and threatened/ endangered species habitat without compensation.

\section{Factor Analysis}

The results of the Principal Components Factor Analysis conducted to identify clusters of similar responses regarding the

Table 2. Mean response values $\pm 95 \%$ confidence intervals $(\mathrm{Cl})$ for implementing six socially desirable rangeland management objectives without compensation $(+3=$ strongly agree $\ldots 0=$ neutral $\ldots-3=$ strongly disagree), and the significance of interstate differences among these responses. Bold statistics indicate significant differences at $P<0.050$.

\begin{tabular}{|c|c|c|c|c|c|c|}
\hline \multirow[b]{2}{*}{ Management objective } & \multicolumn{2}{|c|}{ Overall responses } & \multicolumn{4}{|c|}{ Interstate differences } \\
\hline & $\begin{array}{c}\text { Mean } \pm 95 \% \\
\mathrm{Cl}\end{array}$ & $\begin{array}{l}\text { Prob. that } \\
\text { mean }=0\end{array}$ & Diff. $F(P)$ & $\begin{array}{l}\text { TX vs. UT } \\
t(P)\end{array}$ & $\begin{array}{l}\text { TX vs. CO } \\
\quad t(P)\end{array}$ & $\begin{array}{l}\text { UT vs. CO } \\
\qquad t(P)\end{array}$ \\
\hline Control noxious weeds & $0.59 \pm 0.18$ & $<0.001$ & $51.87(<0.001)$ & $-8.70(<0.001)$ & $-8.53(<0.001)$ & $1.41(0.161)$ \\
\hline Protect quality \& supply of water & & & & & & \\
\hline used on land & $1.52 \pm 0.15$ & $<0.001$ & $4.42(0.012)$ & $-2.88(0.004)$ & $-1.65(0.100)$ & $1.78(0.076)$ \\
\hline Protect water quality \& supply & & & & & & \\
\hline for downstream & $1.48 \pm 0.15$ & $<0.001$ & $1.77(0.171)$ & $-1.61(0.108)$ & $<0.00(0.997)$ & $1.92(0.056)$ \\
\hline Protect wetland \& riparian areas & $0.27 \pm 0.16$ & $=0.001$ & $4.12(0.017)$ & $-1.39(0.165)$ & $-2.76(0.006)$ & $-1.11(0.276)$ \\
\hline Provide access for native wildlife hunting & $-2.19 \pm 0.12$ & $<0.001$ & $0.04(0.964)$ & $0.23(0.817)$ & $<0.00(0.997)$ & $0.28(0.783)$ \\
\hline $\begin{array}{l}\text { Protect threatened \& endangered } \\
\text { species habitat }\end{array}$ & $-0.79 \pm 0.17$ & $<0.001$ & $4.28(0.014)$ & $-1.45(0.148)$ & $-2.90(0.004)$ & $-1.09(0.276)$ \\
\hline
\end{tabular}


Table 3. Rotated component matrices extracted (Principal Component Analysis with Varimax rotation) from responses to statements about six socially desirable rangeland management objectives, implementation of which would be required without public compensation. Bold values emphasize the indices for management objectives that are related.

\begin{tabular}{llc}
\hline & \multicolumn{2}{c}{ Component } \\
\cline { 2 - 3 } \multicolumn{1}{c}{ Management objective } & I & II \\
\hline Control noxious weeds & $\mathbf{0 . 6 7 7}$ & 0.224 \\
Protect quality \& supply of water used on land & $\mathbf{0 . 9 1 7}$ & 0.092 \\
Protect water quality \& supply for downstream & $\mathbf{0 . 8 8 6}$ & 0.074 \\
Protect wetland \& riparian areas & $\mathbf{0 . 7 0 1}$ & 0.332 \\
Provide access for native wildlife hunting & 0.027 & $\mathbf{0 . 8 8 3}$ \\
Protect threatened \& endangered species habitat & 0.375 & $\mathbf{0 . 7 2 6}$ \\
\hline
\end{tabular}

6 identified management objectives are presented in Table 3. Based on this analysis, 2 potential additive subscales were identified: Subscale I included control of noxious weeds, protection of on-site and off-site water supply; and protection of wetland and riparian areas, and Subscale II combined public access for hunting and the protection of habitat for threatened or endangered species (Nair 2004). The reliability analysis of the 2 additive subscales, conducted to determine their robustness, produced a Cronbach's $\alpha$ of 0.835 for the Subscale I and 0.571 for Subscale II. A Cronbach's $\alpha$ of 0.8 or higher is considered acceptable for most social science applications (UCLA Academic Technology Services 2004). Thus the results of the reliability analysis indicated the items associated with the Subscale I have similar answer patterns, whereas items associ- ated with Subscale II are less similar in the minds of the respondents. This suggests that that the additive Subscale I is a reasonable proxy for a cluster of the first 4 land use objectives, and the components in Subscale II should be analyzed separately.

\section{Regression Analyses}

The results of 3 regression analyses are presented in Table 4 . These analyses explore the extent to which variation in response values for 3 land management variables can be explained by 18 independent variables grouped into 4 categories: sociodemographics, enterprise characteristics, property rights orientation indices, and state dummy variables.

The first regression analysis explores how much of the variation in Subscale I scores (willingness to control noxious weeds and wetland/riparian areas, and adopt quality-water supply practices) can be explained by the independent variables. The results show that respondents with higher income and larger proportions of income from wildlife or recreation enterprises are more receptive to the idea that they should practice ecologically sound management with respect to noxious weed control, and water/wetland/riparian area protection without compensation. By contrast, respondents with larger properties and with crop related income are less willing than respondents with smaller properties to implement management practices to meet these socially desirable objectives on their property without compensation. The increasing total cost of implementing such practices on larger properties could explain this response pattern.

Table 4. Results of ordinary least squares regression analyses for Subscale I (derived from respondent agreement with noxious weed and waterrelated rangeland management objectives), provision of access for hunting, and protection of habitat for threatened and endangered species all without compensation (bolded variables are significant at $P<0.100$ ).

\begin{tabular}{|c|c|c|c|c|c|c|c|c|c|}
\hline \multirow[b]{2}{*}{ Variable } & \multicolumn{3}{|c|}{$\begin{array}{c}\text { Subscale I Adj. } \\
R^{2}=0.196, P<0.001\end{array}$} & \multicolumn{3}{|c|}{$\begin{array}{c}\text { Provide access } \\
\text { for hunting Adj. } \\
R^{2}=0.079, P<0.001\end{array}$} & \multicolumn{3}{|c|}{$\begin{array}{c}\text { Protect endangered } \\
\text { species Adj. } \\
R^{2}=0.146, P<0.001\end{array}$} \\
\hline & $\beta$ coeff. & $t$-value & $P$-value & $\beta$ coeff. & $t$-value & $P$-value & $\beta$ coeff. & $t$-value & $P$-value \\
\hline Age of respondent & 0.057 & 0.984 & 0.326 & 0.209 & 3.401 & 0.001 & 0.075 & 1.259 & 0.209 \\
\hline Formal education & -0.027 & -0.548 & 0.584 & -0.100 & -1.942 & 0.053 & -0.072 & -1.445 & 0.149 \\
\hline Years of experience & 0.009 & 0.139 & 0.889 & 0.026 & 0.369 & 0.712 & -0.045 & -0.678 & 0.498 \\
\hline Grew up on property & 0.044 & 0.898 & 0.370 & 0.007 & 0.127 & 0.899 & 0.035 & 0.716 & 0.474 \\
\hline Currently living on property & 0.055 & 1.149 & 0.251 & -0.002 & -0.035 & 0.972 & 0.011 & 0.220 & 0.826 \\
\hline Total household income & 0.108 & 2.236 & 0.026 & -0.021 & -0.402 & 0.688 & 0.086 & 1.737 & 0.083 \\
\hline Hectares owned & -0.142 & -3.065 & 0.002 & 0.005 & 0.096 & 0.924 & -0.055 & -1.163 & 0.246 \\
\hline Crop income & -0.136 & -1.917 & 0.056 & 0.081 & 1.078 & 0.282 & 0.012 & 0.155 & 0.877 \\
\hline Wildlife and recreational income & 0.157 & 1.980 & 0.048 & -0.047 & -0.593 & 0.553 & 0.137 & 1.785 & 0.075 \\
\hline Livestock income & 0.043 & 0.670 & 0.504 & 0.004 & 0.063 & 0.950 & -0.042 & -0.648 & 0.517 \\
\hline Proportion of income from land & -0.039 & -0.776 & 0.438 & 0.025 & 0.471 & 0.638 & -0.065 & -1.302 & 0.194 \\
\hline Profit in 2001 & -0.039 & -0.853 & 0.394 & -0.009 & -0.176 & 0.860 & 0.006 & 0.129 & 0.897 \\
\hline Individual rights index & 0.055 & 1.073 & 0.284 & 0.003 & 0.058 & 0.954 & 0.024 & 0.468 & 0.640 \\
\hline Social responsibility index & 0.185 & 3.792 & $<0.001$ & 0.146 & 2.842 & 0.005 & 0.280 & 5.690 & $<0.001$ \\
\hline Land stewardship index & 0.232 & 5.102 & $<0.001$ & 0.048 & 1.010 & 0.313 & 0.046 & 0.996 & 0.320 \\
\hline Rights erosion index & -0.093 & -1.901 & 0.058 & -0.087 & -1.685 & 0.093 & -0.131 & -2.635 & 0.009 \\
\hline Dummy for Texas & -0.309 & -4.905 & $<0.001$ & 0.084 & 1.281 & 0.201 & -0.094 & -1.475 & 0.141 \\
\hline Dummy for Colorado & -0.021 & -0.327 & 0.744 & 0.034 & 0.519 & 0.604 & 0.065 & 1.018 & 0.309 \\
\hline
\end{tabular}


Of greater interest is the power of the property rights orientation indices for explaining the differences in respondent attitudes towards socially desirable rangeland management objectives. Three of the 4 additive property rights orientation indices were significant with respect to Subscale I, the exception being the individual rights index. The results suggest that respondents who scored high with respect to social responsibility and land stewardship orientations were more willing than those with lower scores to adopt socially desirable land management objectives represented by Subscale I. Conversely, respondents who felt more strongly that their private property rights were being threatened expressed less willingness to adopt such management objectives without compensation. The dummy variable for Texas was also found to be statistically significant suggesting that Texas respondents were less willing to adopt such land management objectives than respondents from Utah and Colorado, which have more public land. This is consistent with the interstate differences presented in Table 2.

The results of the other 2 regression analyses presented in Table 4 relate to the provision of access for hunting of native game species on private land and the protection of habitat for threatened or endangered species without compensation. With respect to access for hunting, older respondents were more amenable to the idea of allowing free access for hunting on their land, whereas more educated respondents were less amenable to this idea; younger respondents generally have more formal education. These response patterns might, therefore, be explained by younger respondents' greater financial need, their greater awareness of income opportunities form hunting, or a combination thereof. Statistically significant coefficients for property rights indices with respect to the provision of free hunting access included the social responsibility and rights erosion indices. Respondents with a high social responsibility score appeared more willing to allow free access for hunting on their land, whereas those who perceived their rights to be threatened were less willing.

In the regression analysis pertaining to the idea that landowners should protect threatened or endangered species habitat without compensation, results suggest that respondents with a higher level of income and those who derived wildlife or recreation-related income from their land were more willing to do so. This might be because they are less dependent on their land for income or they incur no extra direct cost if such habitat is already an integral component of habitat that is suitable for economically valuable species. It also might be that respondents who are wealthier or who derive wildliferelated income simply place greater value on endangered species than those who do not. The other socio-demographic and enterprise variables were found to be statistically nonsignificant. However, respondents who expressed a greater sense of social responsibility also expressed greater willingness to protect threatened and endangered species habitat. Conversely, those respondents who felt more strongly that their property rights were being threatened appeared to be less inclined to protect such habitat possibly because of concerns about the constraints that legislation, specifically the Endangered Species Act, places on land uses that impact endangered species habitat.

\section{DISCUSSION AND CONCLUSION}

The objective of our study was to explore landowner attitudes regarding the uncompensated adoption of socially desirable rangeland management objectives that enhance the delivery of ecosystem services. We were specifically interested in determining how landowners' property rights orientations might influence these attitudes. In conducting the study, we assumed that rangeland management practices that enhance the delivery of ecosystem services are ecologically sound. The factor analysis revealed the existence of 2 distinct clusters of practices: one includes the control of noxious weeds, and the protection of wetlands/riparian areas and on- and off-site water supplies; and the other reflects attitudes towards the provision of free access for hunting and the protection of threatened/endangered species habitat. However, the subscale associated with the latter cluster did not satisfy the reliability conditions; thus, the 2 subcomponents were included in separate ordinary least squares regression analyses.

None of the variables in the socio-demographic or landowner or enterprise characteristic categories were statistically significant in more than 1 of the 3 regression analyses, thereby preventing generalizations about the influence of these variables on respondents attitudes toward adopting socially desirable land management objectives. By contrast, the results of the 3 regression analyses corroborated our hypothesis that landowner property rights orientations affect their willingness to adopt socially desirable rangeland management practices without public compensation. The social responsibility dimension of property rights orientations was highly significant in all 3 regressions for explaining attitudinal differences regarding the notion that landowners should adopt socially desirable rangeland management objectives without compensation. On the other hand, respondents who felt strongly that their property rights are being eroded disagreed strongly with this notion. The index for land stewardship was positively correlated with this notion in only 1 regression. Surprisingly, the coefficient for the fourth dimension of landowners' property rights orientations, individual rights, was not significant in any regression. Based on the historical assumption that individual rights and social responsibility lie at opposite ends of a bipolar axis (JacksonSmith et al. 2005), one might have expected a statistically significant negative coefficient for the private rights index.

The state in which landowners live also influenced their willingness to adopt 4 land management objectives. Texas respondents were less willing to control noxious weeds, and to protect on-site water supply and quality, wetland/riparian areas, and threatened/endangered species habitat without compensation than Utah or Colorado respondents. Based on these findings, we hypothesize that landowners in states with significant areas of public land might be less resistant to managing land in ways that enhance the delivery of socially desirable ecosystem services compared to landowners in private land states. On one hand, this hypothesis might seem counterintuitive because in public land states (e.g., Utah and Colorado) landowners might be expected to feel little obligation to provide ecosystem services because they perceive that public lands do that, whereas in private land states (e.g., Texas) landowners might be expected to feel a stronger obligation to do so because 
of the lack of public land. On the other hand, landowners who depend on public land for forage and are, therefore, subject to various restrictions on the use of public rangelands might have a greater general sense of social responsibility regarding the delivery of ecosystem services from rangelands. Due to these contrasting possibilities, the relationship between the proportion of public land in a state and the influence of landowner property rights orientations on their decisions about the management of rangelands should be explored further in a more extensive study.

Evolution of property rights in the face of changing social values is inevitable, but socially driven changes to individual property rights are almost often contentious. Although the results of our study cannot be generalized due to the small number of counties selected for the study, our results provide some intriguing possibilities that should be further explored. For example, our study suggests that reinforcing private property rights to alleviate landowner concerns about the erosion of such rights could be important for increasing landowner willingness to adopt land management practices that enhance the delivery of ecosystem services on privately owned rangelands. Similarly, agencies whose goal it is to facilitate the maintenance of ecosystem services on private rangelands might more successfully achieve this goal if they focus on fostering the social responsibility dimension of property rights perceptions in order to increase the adoption of socially desirable management objectives by landowners. For example, inclusion of rural community leaders with a high sense of social responsibility in educational and incentive programs might lead to greater acceptance of social responsibility perspectives among neighboring landowners through the passive diffusion of values among peers or through peerpressure programs such as Australia's Landcare program. Finally, the statistical significance of the Texas state variable in 1 regression analysis suggests that government agencies should develop such programs at the state rather than the national level to take into account differences among landowner property-rights orientations relative to their dependence on private and public land as their "production base."

Due to the small number of states included in our landowner survey, we are unable to draw broad conclusions from our results. However, our study does suggest that landowners' propery rights orientations could have important land management policy implications and should, therefore, be tested in a comprehensive way across more states and counties.

\section{MANAGEMENT IMPLICATIONS}

Rangelands around the world provide ecosystem services that are critical for the survival and welfare of human beings. Because many rangelands in the western United States occur on privately owned land, management decisions that affect vegetation composition on private rangelands have a direct bearing on the delivery of ecosystem services that are important to human societies. For example, quality water supplies, properly functioning wetlands/riparian areas, and suitable habitat for endangered species are often directly affected by private vegetation management decisions. Therefore, if landowners, who feel a lack of social responsibility relative to their property rights or who sense a loss of sovereignty over their land, are disinclined to adopt land management decisions that enhance the delivery of such ecosystem services, human societies will likely suffer in the long term. Our study found that a weak sense of social responsibility among respondents and feelings that property rights are being threatened were associated with a reluctance by landowner to adopt management objectives related to the delivery of socially important ecosystem services. Although the results of our study cannot be generalized, because they were derived from only 6 counties in 3 states, they suggest some interesting possibilities that have potentially important implications for agencies that focus on enhancing ecosystem services. Specifically, our study suggests that in attempting to modify management practices on private rangelands, land management agencies need to be sensitive to specific aspects of landowners' property rights perceptions. Therefore, the results of our study have relevance for policy makers trying to formulate landowner-friendly policies aimed at improving land management practices that enhance critical ecological services from rangelands.

\section{LITERATURE CITED}

Anderson, T. L., And D. R. Leal. 1991. Free market environmentalism. Boulder, CO: Westview Press Inc. 192 p.

Anderson, T. L., and F.S. McChesney [eds.]. 2003. Property rights: Cooperation, conflict and law. Princeton, NJ: Princeton University Press. $398 \mathrm{p}$.

Berkes, F., AND C. Folke. 1998. Linking social and ecological systems: Management practices and social mechanisms for building resistance. Cambridge, UK: Cambridge University Press. 459 p.

BıIss, J. C., M. L. SISOCK, AND T. W. BIRCH. 1998. Ownership matters: forestland concentration in rural Alabama. Society and Natural Resources 11:401-410.

Bromley, D. W. 1991. Environment and economy: Property rights and public policy. Cambridge, MA: Blackwell. $247 \mathrm{p}$.

CoLE, D. H. 2002. Pollution and property: Comparing ownership institutions for environmental protection. Cambridge, UK: Cambridge University Press. 209 p.

Coppock, L. D., AND A. H. BiRKEnfeld. 1999. Use of livestock and range management practices in Utah. Journal of Range Management 52:7-18.

CuRTIS, A. 1998. Agency-community partnership in landcare: lessons for statesponsored citizen resource management. Environmental Management 22:563-574.

Curtis, A., And M. Lockwood. 2000. Landcare and catchment management in Australia: lessons for state-sponsored community participation. Society and Natural Resources 13:61-73.

Dillman, D. A. 2000. Mail and Internet surveys: The tailored design method. 2nd ed. New York, NY: John Wiley and Sons. 464 p.

FugLIE, K. O., AND C. A. KASCAK. 2001. Adoption and diffusion of natural-resourceconserving agricultural technologies. Review of Agricultural Economics 23:386-403.

GueRIN, T. F. 1999. An Australian perspective on the constraints to the transfer and adoption of innovations in land management. Environmental Conservation 26:289-304.

Hardin, G. 1968. The tragedy of the commons. Science 13:1243-1248.

HARNETT-WHITE, K. 1994. Why are property rights important to responsible management? In: L. D. White [ED.]. Private property rights and responsibilities of rangeland owners and managers. Proceedings of Workshop, Austin, TX. College Station, TX: Cooperative Extension. p 25-29.

Honoré, A. M. 1961. Chapter 5-Ownership. In: A. G. Guest [ED.]. Oxford essays in jurisprudence. Oxford, UK: Oxford University Press. p 107-147.

Jackson-Smith, D. 2004. The social aspects of agriculture. In: M. J. Manfredo, J. J. Vaske, D. R. Field, P. J. Brown, and B. L. Bruyere [eDs.]. Society and 
natural resources: A summary of knowledge. Jefferson City, M0: Modern Litho. p 159-174.

Jackson-Smith, D., U. P. Kreuter, and R. S. Krannich. 2005. Understanding the multidimensionality of property rights orientations: evidence from Utah and Texas ranchers. Society and Natural Resources 18:587-610.

Knight, R. L., W. C. Gilbert, and E. Marston [eds.]. 2002. Ranching west of the 100th meridian: Culture, ecology, and economics. Washington, DC: Island Press. $259 \mathrm{p}$.

KoRsCHING, P. F., AND T. J. Hoban. 1990. Relationships between information sources and farmers' conservation perceptions and behavior. Society and Natural Resources 3:1-10.

Kreuter, U. P., H. G. Harris, M. D. Matlock, and R. E. Lacey. 2001a. Estimates of ecosystem services in San Antonio, Texas. Ecological Economics 39: 333-346.

Kreuter, U. P., H. E. Amestoy, D. N. Ueckert, and W. A. McGinty. 2001b. Adoption of brush busters: results of Texas county extension survey. Journal of Range Management 54:630-639.

McGranahan, D. A. 1999. Natural amenities drive rural population change. AER781. Washington, D.C.: Economic Research Service, US Department of Agriculture. $24 \mathrm{p}$.

NAIR, M. V. 2004. Property rights orientations of landowners in Texas, Utah and Colorado [dissertation]. College Station, TX: Texas A\&M University. $157 \mathrm{p}$.

NAPIER, T. L. 2000. Use of soil and water protection practices among farmers in the north central region of the United States. Journal of the American Water Resources Association 36:723-35.

Napier, T. L., M. Tucker, and S. McCarter. 2000. Adoption of conservation production systems in three midwest watersheds. Journal of Soil and Water Conservation (2nd Qtr.):123-134.

Norusis, M. J. 1990. SPSS advanced statistics student guide. Chicago, IL: SPSS Inc. $506 \mathrm{p}$.

Nowak, P. 1992. Why farmers adopt production technology. Journal of Soil and Water Conservation 47:14-16.

Ostrom, E. 2001. Reformulating the commons. In: J. Burger, E. Ostrom, R.
Norgaard, D. Policansky, and B. D. Goldstein [EDS.]. Protecting the commons: A framework for resource management in the Americas. Washington, DC: Island Press. p 17-44.

Perry, M. J. and P. J. Mackun. 2001. Population change and distribution. Washington, DC: U.S. Census Bureau. Available at http://www.census.gov/ prod/2001pubs/c2kbr01-2.pdf. Accessed 1 December 2001.

Peterson, R. 1997. Coping strategies of Utah grazing permittees under economic and social pressure [thesis]. Logan, UT: Utah State University. $132 \mathrm{p}$.

Rowan, R. C. 1994. Are small-acreage livestock producers real ranchers? Rangelands 16:161-166.

Rowan, R. C., H. W. Ladewig, and L. D. White. 1994. Perceptions vs. recommendations: a rangeland decision-making dilemma. Journal of Range Management 47:344-348.

StATSOFT Inc. 2004. Reliability and item analysis. http://www.statsoft.com/ textbook/streliab.html. Accessed 9 August 2004.

UCLA Academic Technology Services. 2004. What does Cronbach's Alpha do? http:// www.ats.ucla.edu/stat/spss/faq/alpha.html. Accessed 9 August 2004.

WHITE, L. D. 1988. Technology transfer and total ranch management. In: R. S. White and R. E. Short [EDS.]. Achieving efficient use of rangeland resources. Proceedings of the Fort Keogh Research Symposium: Achieving efficient use of rangeland resources. Bozeman, MT: Montana Agricultural Experiment Station. p 125-128.

Wiebe, K., A. Tegene, and B. Kuhn. 1999. Finding common ground on western lands. Rural Development Perspectives 14:52-56.

Workman, J. P., and S. G. Evans. 1993. Utah ranches-An economic snapshot. Rangelands 15:253-255.

Workman, J. P., And S. G. Evans. 1996. Optimum cattle management on Utah ranches. Rangelands 18:27-29.

Young, M. D., AND B. J. McCay. 1995. Building equity, stewardship, and resilience into market-based property rights systems. In: S. Hann and M. Munasinghe [EDS.]. Property rights and the environment: Social and ecological issues. Washington, DC: World Bank. p 87-102. 